\title{
Hair Cell Overexpression of Islet1 Reduces Age-Related and Noise-Induced Hearing Loss
}

\author{
Mingqian Huang, ${ }^{1,2}$ Albena Kantardzhieva, ${ }^{1,2}$ Deborah Scheffer, ${ }^{1,2,3}$ M. Charles Liberman, ${ }^{1,2}$ and Zheng-Yi Chen ${ }^{1,2}$ \\ ${ }^{1}$ Department of Otology and Laryngology, Harvard Medical School, Boston, Massachusetts 02115, ${ }^{2}$ Eaton-Peabody Laboratories, Massachusetts Eye and Ear \\ Infirmary, Boston, Massachusetts 02114, ${ }^{3}$ Howard Hughes Medical Institute and Department of Neurobiology, Harvard Medical School, Boston, \\ Massachusetts 02115
}

Isl1 is a LIM-homeodomain transcription factor that is critical in the development and differentiation of multiple tissues. In the mouse inner ear, Isl1 is expressed in the prosensory region of otocyst, in young hair cells and supporting cells, and is no longer expressed in postnatal auditory hair cells. To evaluate how continuous Isll expression in postnatal hair cells affects hair cell development and cochlear function, we created a transgenic mouse model in which the Pou $4 \mathrm{f3}$ promoter drives Isl1 overexpression specifically in hair cells. Isl1 overexpressing hair cells develop normally, as seen by morphology and cochlear functions (auditory brainstem response and otoacoustic emissions). As the mice aged to 17 months, wild-type (WT) controls showed the progressive threshold elevation and outer hair cell loss characteristic of the age-related hearing loss (ARHL) in the background strain (C57BL/6J). In contrast, the Isl1 transgenic mice showed significantly less threshold elevation with survival of hair cells. Further, the Isl1 overexpression protected the ear from noise-induced hearing loss (NIHL): both ABR threshold shifts and hair cell death were significantly reduced when compared with WT littermates. Our model suggests a common mechanism underlying ARHL and NIHL, and provides evidence that hair cell-specific Isl1 expression can promote hair cell survival and therefore minimize the hearing impairment that normally occurs with aging and/or acoustic overexposure.

\section{Introduction}

Nearly one-third of adults over 64 have significant hearing loss, and the percentage almost doubles $(62.1 \%)$ for those over 85 (Schoenborn and Heyman, 2009). Age-related hearing loss (ARHL) is the result of interactions between genetic predisposition and the aging process with a variety of lifetime insults to the ear (Bielefeld et al., 2010). Noise-induced hearing loss (NIHL) is one of the most self-reported occupational injuries (National Institute for Occupational Safety and Health, 2001). The irreversible loss of inner ear outer hair cells (OHCs), with the function to amplify mechanical vibrations, is one of the main reasons for hearing loss in NIHL and ARHL (Spongr et al., 1997; Hequembourg and Liberman, 2001; Liberman et al., 2002; Wang et al., 2002).

Some inbred strains of mice show shared susceptibilities to NIHL and ARHL, an indication of related mechanisms. For example, $\mathrm{CBA} / \mathrm{CaJ}$ mice retain normal hearing up to $\geq 18$ months of age, whereas $\mathrm{C} 57 \mathrm{BL} / 6 \mathrm{~J}$ mice lose hair cells and show significant hearing loss by 6 months of age (Henry and Chole, 1980; Trune et

\footnotetext{
Received April 8, 2013; revised Aug. 6, 2013; accepted Aug. 11, 2013.

Author contributions: Z.-Y.C. designed research; M.H., A.K., D.S., and Z.-Y.C. performed research; M.H., A.K., M.C.L., and Z.-Y.C. analyzed data; M.H., M.C.L., and Z.-Y.C. wrote the paper.

This work was supported by National Institutes of Health grants (R01 DC06908 to Z.-Y.C., R01 DC 00188 to M.C.L., and P30 DC 05029 to M.C.L.), a grant from the Capita Foundation (Z.-Y.C.), a grant from the Ellison Foundation (Z.-Y.C.), by the Fredrick and Ines Yeatts Inner Ear Hair Cell Regeneration Fellowship to M.H. and A.K., and by a grant from the Bertarelli Foundation (Z.-Y.C.).

A patent application on the results has been filed.

Correspondence should be addressed to Zheng-Yi Chen, Eaton-Peabody Laboratory, Massachusetts Eye and Ear Infirmary, 243 Charles St., Boston, Massachusetts 02114. E-mail: zheng-yi_chen@meei.harvard.edu.

DOI:10.1523/JNEUROSCI.1489-13.2013

Copyright $\odot 2013$ the authors $\quad 0270-6474 / 13 / 3315086-09 \$ 15.00 / 0$
}

al., 1996; Spongr et al., 1997; White et al., 2000; Hequembourg and Liberman, 2001). CBA/CaJ mice are also less vulnerable to NIHL than C57BL/6J mice (Erway et al., 1996). A mutation in cadherin 23, a component of the stereocilia tip links, has been identified as the cause of ARHL in C57BL/6J (Noben-Trauth et al., 2003), yet the mechanism underlying good hearing in CBA/ $\mathrm{CaJ}$ is unknown. If NIHL and ARHL share some of the same underlying mechanisms, similar molecular approaches to their prevention might be effective.

Here, we investigated whether overexpression of Isll, an inner ear progenitor gene with roles in development and differentiation, could be effective in protecting the inner ear. This is based on a hypothesis that overexpression of developmental genes in mature hair cells may lead to reprogramming and rejuvenation of aged and noise-damaged hair cells, rendering them the capacity to better repair hair cells in aging and when exposed to noise. Isl1 is a LIM-homeodomain transcription factor with $100 \%$ identity across most mammalian species. It contains two LIM domains for protein-protein interaction and one homeodomain for DNA binding (Karlsson et al., 1990; Hobert and Westphal, 2000). Isl1 is critical in the development and differentiation of the nervous system (Thaler et al., 2002), pituitary, pancreas, heart (Ahlgren et al., 1997; Laugwitz et al., 2005), and retinal ganglion neurons (Elshatory and Gan, 2008; Mu et al., 2008; Sun et al., 2008). It regulates its target genes in a tissue-dependent manner (Cai et al., 2003; Lin et al., 2006). In the developing inner ear, Isl1 expression correlates with the prosensory domain formation, whereas in neonatal inner ear, Isl1 is no longer expressed in hair cells (Huang et al., 2008). We created a transgenic mouse model to overexpress Isll in the in 
A
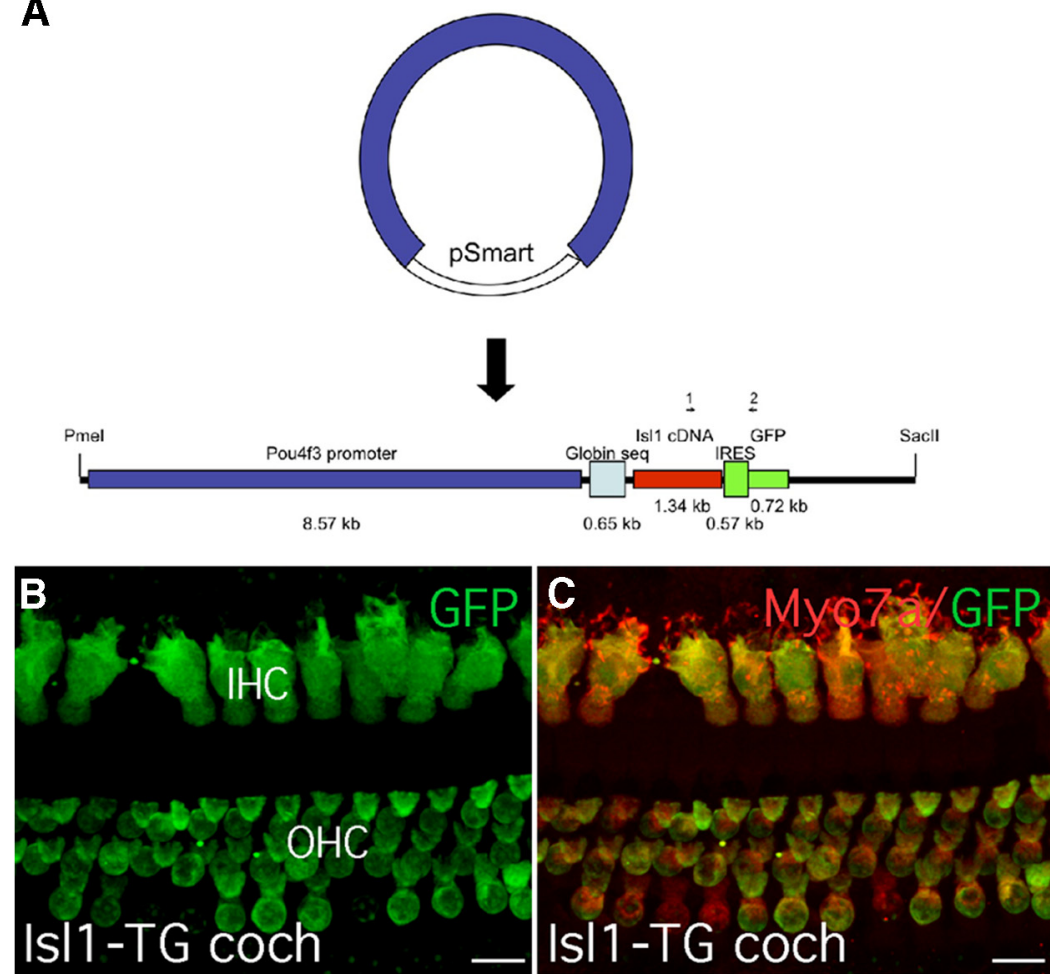

\section{D}

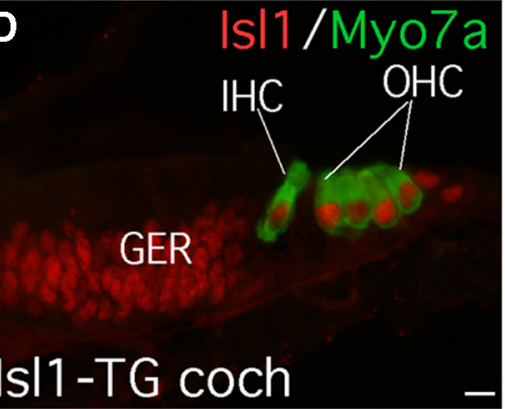

$\mathbf{F}$

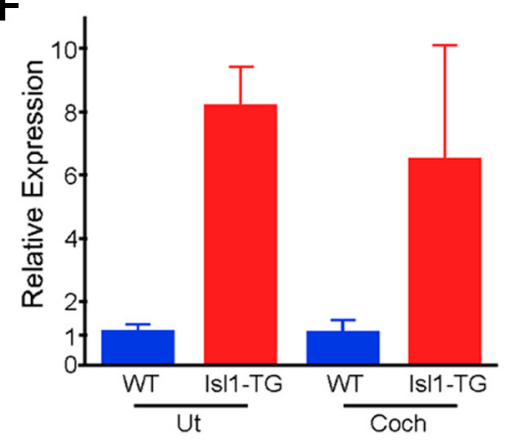

Figure 1. Construction and characterization of Is/1-TG mice. A, A schematic diagram depicting the construction of the Pou4f3 promoter driven Is/1 expression, with an IRES signal that links an EGFP ORF as a separate marker. The total size of the construct is $\sim 14 \mathrm{~kb}$. Positions of genotyping primers are also shown. $B, C, \operatorname{In} 20$-month-old /s 1/-TG mouse cochlea, GFP signal was detected in all OHCS $(\boldsymbol{B})$ and inner hair cells $(\boldsymbol{B}, \mathrm{IHC})$ and was colocalized with MY07A-labeled hair cells (C). $\boldsymbol{D}, \boldsymbol{E}$, In P1 Is/1-TG cochlea, Is/1 transgene expression was detected in all hair cells $(\boldsymbol{D})$, whereas in the WT control cochlea, endogenous $/ s / 1$ was no longer detectable in hair cells $(\boldsymbol{E})$. $\boldsymbol{F}$, qRT-PCR of 3-month-old adult showed overexpression of $/ s / 1$ in the $/ s / 1-T G$ compared with WT control inner ear tissues. Expression levels were normalized with control gene Pgk1. Ut, Utricle; Coch, cochlea. Is/1-TG, $n=2 ; \mathrm{WT}, n=3$. Error bars indcate mean ( \pm SEM). Scale bar, $10 \mu \mathrm{m}$.

postnatal hair cells by the control of the Poutf3 promoter (Sage et al., 2006). We show that hair cell-specific Isll expression promotes hair cell survival, leading to significant hearing preservation against both ARHL and NIHL.

\section{Materials and Methods}

Generation of transgenic mice. Rat Isl1 cDNA clone was purchased from RIKEN and sequenced to verify the accuracy. A $1.4 \mathrm{~kb}$ fragment containing $I s l l \mathrm{cDNA}$ was cut out from the pFLCI vector and blunt-ended, then inserted into pCLCMV- $\beta$-actin-IRES-GFP vector in front of IRES-GFP. The Isl1-IRES-GFP fragment was then cut with StuI and NaeI, and ligated with a pSmart VC vector to create pSmart- $\beta$-globinIsl1-IRES-GFP-polyA construct. This construct was cut with SalI, blunt-ended, and ligated with a $9 \mathrm{~kb}$ fragment of mouse Pou $4 \mathrm{f} 3$ promoter sequence, cut from a vector generously provided by Doug Vetter from Tufts University, to create the final construct pSmart-Pou4f3- $\beta$-globin-Isll-IRES-GFP.

Transgenic mice were created in transgenic mouse core facility of the Massachusetts General Hospital. The final Isll transgene construct was linearized with PmeI and SacII and injected into $\mathrm{B} 6 \mathrm{C} 3 \mathrm{~F} 1$ embryos, which are products of a cross between $\mathrm{C} 57 \mathrm{BL} / 6 \mathrm{NCrlBR}$ and $\mathrm{C} 3 \mathrm{H} /$ HeNCrlBR strains (http://www.criver.com/ENUS/PRODSERV/BYTYPE/RESMODOVER/ RESMOD/Pages/B6C3F1Mice.aspx) and labeled as $\mathrm{C} 57 \mathrm{BL} / \mathrm{C} 3 \mathrm{H}$. The founders were mated with $\mathrm{C} 57 \mathrm{BL} / 6 \mathrm{~J}$ mice, and the offspring were intercrossed for $\geq 5$ generations. For all experiments reported here, transgenic mice of either sex were compared with wild-type (WT) littermates of either sex.

The primers used for genotyping are as follows: 5'-AGCAGCAACCCAACGACAAAAC TA- ${ }^{\prime}$ and $5^{\prime}$-AACTTCAGGGTCAGCTTGCC GTAG-3'. PCR conditions are as follows: $94^{\circ} \mathrm{C}$, $2 \mathrm{~min} ; 94^{\circ} \mathrm{C}, 30 \mathrm{~s} ; 67^{\circ} \mathrm{C}, 1 \mathrm{~min} ; 72^{\circ} \mathrm{C}, 1 \mathrm{~min} 30 \mathrm{~s}$ for 35 cycles; $72^{\circ} \mathrm{C}, 10 \mathrm{~min}$. The expected size of product from transgenic mice is $1140 \mathrm{bp}$. Genotyping of $C d h 23^{a h l}$ mutation was done using the protocol described before (Mashimo et al., 2006). Briefly, a genomic fragment of 194 bp was amplified by PCR using a pair of $C d h 23$ primers. Upon PstI digestion, Cdh $23^{753 A}$ allele produced a fragment of $170 \mathrm{bp}$ whereas WT control remained $194 \mathrm{bp}$. All protocols were approved by the institutional animal care and use committees.

Auditory brainstem response and distortion product otoacoustic emissions tests. For auditory brainstem response (ABR) and distortion product otoacoustic emissions (DPOAE) tests (Kujawa and Liberman, 2009), mice of either sex were anesthetized with xylazine $(10 \mathrm{mg} / \mathrm{kg}$, i.p.) and ketamine (100 $\mathrm{mg} / \mathrm{kg}$, i.p.). Acoustic stimuli were delivered using a custom acoustic assembly consisting of two electrostatic earphones to generate primary tones and a miniature microphone to record ear-canal sound pressure.

For measurement of ABRs, needle electrodes were inserted at vertex and pinna, with a ground near the tail. ABR potentials were evoked with $5 \mathrm{~ms}$ tone pips ( $0.5 \mathrm{~ms}$ rise-fall with a $\cos ^{2}$ onset, delivered at 35/s). The response was amplified $(10,000 \times)$, filtered $(100 \mathrm{~Hz}-3 \mathrm{kHz})$, digitized, and averaged (1024 responses). Sound level was raised in $5 \mathrm{~dB}$ steps from $10 \mathrm{~dB}$ below threshold up to $80 \mathrm{~dB}$ SPL. Upon visual inspection of stacked waveforms, "thresh- 
old" was defined as the lowest SPL level at which any wave could be detected.

For measurement of DPOAEs at 2f1- $\mathrm{f} 2$, the primary tones were set so that the frequency ratio (f2/f1) was 1.2 and so that $\mathrm{f} 2$ level was $10 \mathrm{~dB}$ below $\mathrm{f} 1$ level. For each $\mathrm{f} 2 / \mathrm{f} 1$ primary pair, levels were swept in $5 \mathrm{~dB}$ steps from $20 \mathrm{~dB}$ SPL to $80 \mathrm{~dB}$ SPL (for f2). At each level, the amplitude of the DPOAE at 2f1-f2 was extracted from the averaged spectra, along with the noise floor. Threshold was defined as the $\mathrm{f} 2$ level required to produce a DPOAE at $5 \mathrm{~dB}$ SPL.

For ABR and DPOAE, an investigator without knowledge about the mouse genotypes scored the output that matched the results from the investigator who conducted the tests.

Noise exposure. Mice at 6-7 weeks were exposed to free-field noise, awake and unrestrained, in a small reverberant chamber. An $8-16 \mathrm{kHz}$ octave-band noise was presented either for $2 \mathrm{~h}$ at $100 \mathrm{~dB}$ SPL or for $1 \mathrm{~h}$ at $116 \mathrm{~dB}$ SPL. The exposure stimulus was generated by a custom whitenoise source, filtered (Brickwall Filter with a $60 \mathrm{~dB} /$ octave slope), amplified (Crown power amplifier), and delivered (JBL compression driver) through an exponential horn fitted securely to a hole in the top of a reverberant box.

Statistical analysis. Statistical analyses were performed by ANOVA with Bonferroni corrections for multiple comparisons followed for pairwise comparisons, using the Prism 5.0 statistical analysis program (GraphPad).

Quantitative RT-PCR. Cochleas and utricles were dissected out from the temporal bones of 3-month-old Isl1-TG and WT littermates. The cochlear tissues included the organ of Corti, spiral limbus, and lateral wall. For utricles, the roof membrane and most of the nerve fibers were removed. Total RNA was extracted from cochleas or utricles from adult Isl1-TG and WT mice using RNeasy Mini Kit from Qiagen. cDNA was synthesized using SuperScript II reverse transcriptase (Invitrogen) with random primers. Real-time quantitative PCR amplification reactions for Isl1 gene were performed using TaqMan Gene Expression Assays (Life Technologies) on Mx3000P QPCR system (Agilent Technologies). All reactions were performed in duplicate using the Platinum Quantitative PCR SuperMix-UDG w/ROX (Life Technologies). Expression of the gene was normalized using $P g k 1$ as the endogenous housekeeping control gene. The relative expression level was calculated by the $2^{-\Delta \Delta \mathrm{Ct}}$ method.

Histological processing and analysis. Inner ears were fixed in 4\% paraformaldehyde at $4^{\circ} \mathrm{C}$ overnight, then decalcified in $120 \mathrm{~mm}$ EDTA. The cochlea was dissected in pieces from the decalcified tissue for wholemount immunofluorescence. The antibodies used were as follows: rabbit anti-GFP (1:200; Invitrogen), mouse anti-ISL1 (1:100; clone 40.2D6, Developmental Studies Hybridoma Bank), rabbit anti-MYO7A (1:200; Proteus BioSciences), goat anti-SOX2 (1:200; Santa Cruz Biotechnology), chick anti-neurofilament (NEFH, 1:1000; Millipore Bioscience Research Reagents), mouse anti-CTBP2 (1:200, BD Transduction Labs), goat antiprestin (SLC26A5, 1:500; Santa Cruz Biotechnology), mouse antip27Kip1 (CDKN1B, 1:50; Neomarkers), rabbit anti-PTPRQ (1:1000; gift from Daniel F. Bowen-Pope, University of Washington), rabbit antiPROX1 (1:1000, Millipore Bioscience Research Reagents), mouse antiacetylated tubulin (1:1000, Sigma-Aldrich), mouse anti-PCNA (1:100; Santa Cruz Biotechnology), mouse anti-cleaved caspase-9 (Asp353, 1:50; Cell Signaling Technology). All Alexafluor secondary antibodies were from Invitrogen. Alexa-488-phalloidin was used in 1:600 dilution along with secondary antibodies. For CTBP2/NEFH staining, the following secondary antibodies were added: biotinylated donkey anti-mouse (1: 200; Jackson Immunotech) followed by streptavidin-coupled Alexafluor 568 (1:1000; Invitrogen) and Alexafluor 488-coupled goat anti-chicken (1:1000) followed by Alexafluor 488-coupled chicken anti-goat (1:1000).

Confocal images were taken with a Leica TCS SP5 microscope using a $63 \times$ glycerin-immersion lens, with or without digital zoom. A frequency map was constructed for each case by measuring the spiral extent of all the dissected cochlear pieces and converting cochlear location to frequency using a plug-in of ImageJ (http://www.masseyeandear.org/ research/ent/eaton-peabody/epl-histology-resources/imagej-plugin-forcochlear-frequency-mapping-in-whole-mounts/). To count synaptic ribbons, confocal $z$-stacks were analyzed with Amira software, using the

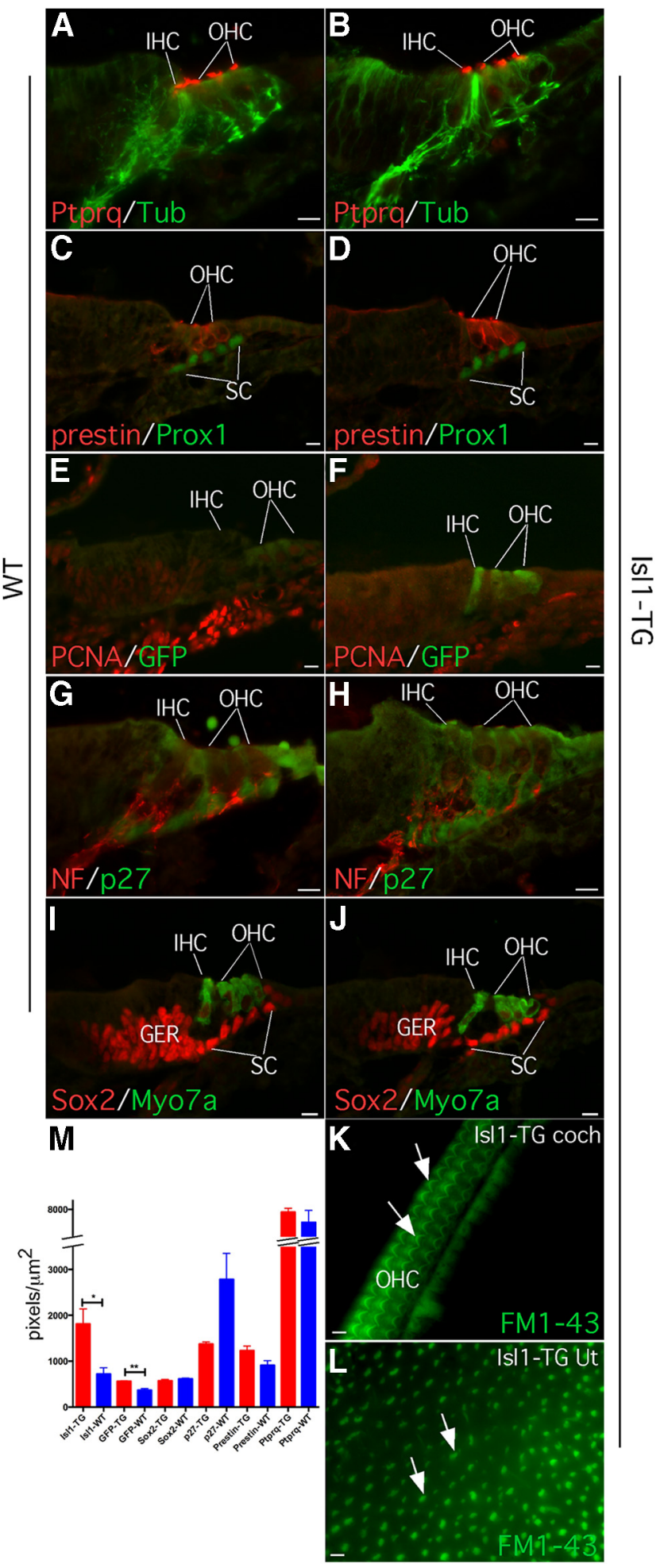

Figure 2. Normal differentiation of $/ s / 1-T G$ inner ear. $\boldsymbol{A}-\boldsymbol{J}$, There is no significant difference in the key protein distribution between IS/1-TG and WT control inner ear and hair cells that include PTPRQ for hair bundles $(\boldsymbol{A}, \boldsymbol{B})$, acetylated tubulin $(\boldsymbol{A}, \boldsymbol{B}$, Tub), and neurofilament $(\boldsymbol{G}, \boldsymbol{H}$, $\mathrm{NF}$ ) for nerve fibers; prestin for $\mathrm{OHC}$, and PROX1 for supporting cells $(C, D) ; P C N A$ for proliferating cells and GFP only in transgenic hair cells $(\boldsymbol{E}, \boldsymbol{F})$, p27KIP1 for supporting cells $(\boldsymbol{G}, \boldsymbol{H})$, SOX2 for supporting cells, and MY07A for hair cells $(\boldsymbol{I}, \boldsymbol{J}) . \boldsymbol{K}, \boldsymbol{L}, \mathrm{FM1}-43$ uptake showed colocalization between GFP fluorescence and hair bundles in P2 Is/7-TG cochlea $(\boldsymbol{K})$ and utricle $(\boldsymbol{L}) . M, A$ diagram depicting signal intensity of genes in hair cells and supporting cells between Is1l-TG and WT cochleas. Only $/ s / 1$ and GFP showed significant increase in the $/ s / 1-T G$ versus WT control hair cells. ${ }^{*} p<0.05 ;{ }^{* *} p<0.01, t$ test. Scale bar, $10 \mu \mathrm{m}$. 

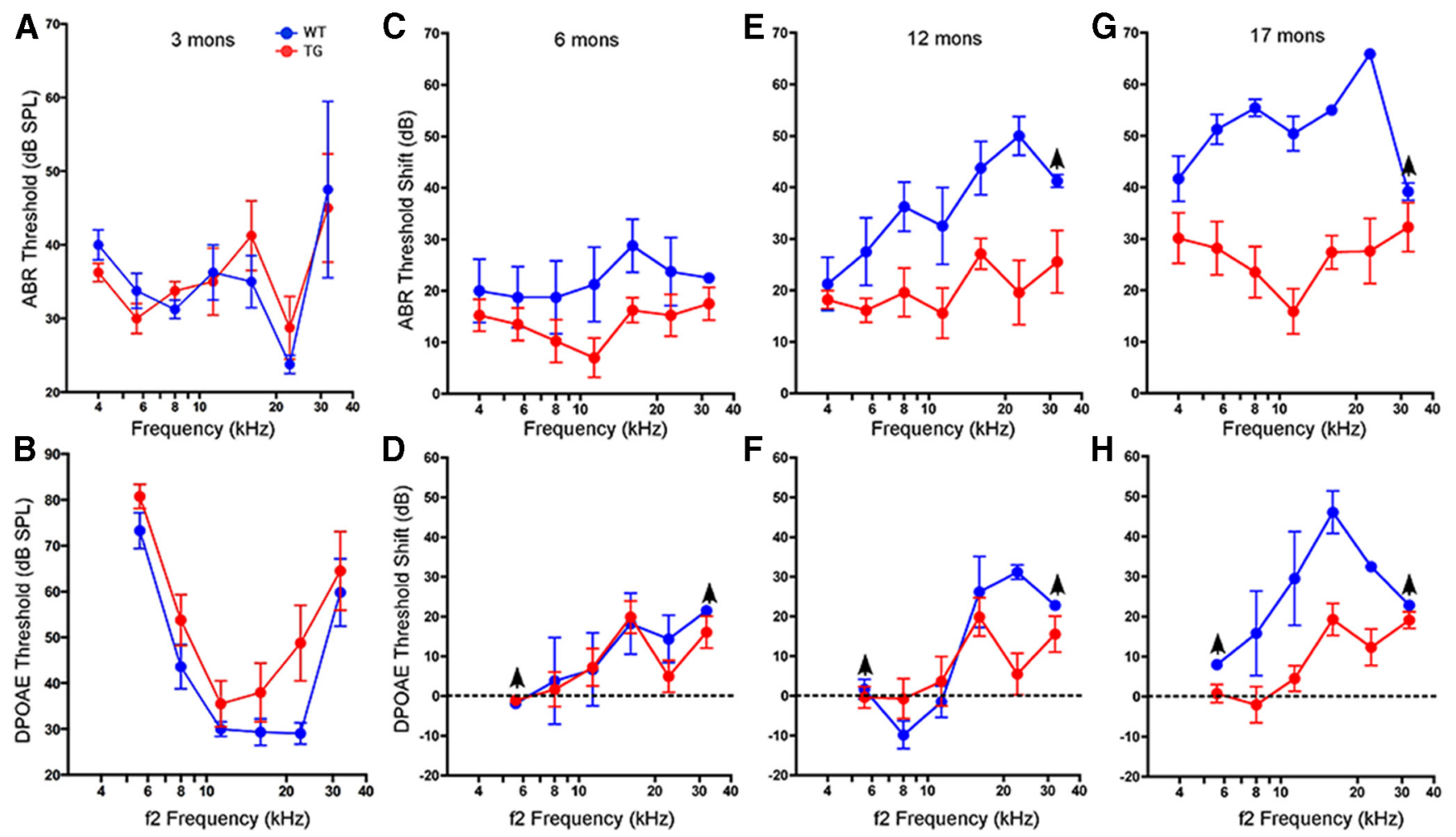

Figure 3. Reduced age-related threshold shift. $\boldsymbol{A}-\boldsymbol{H}$, Age-related threshold shift is reduced in $/ s / 1-T G$ mice, as measured either by ABRs $(\boldsymbol{A}, \boldsymbol{C}, \boldsymbol{E}, \boldsymbol{G})$ or DPOAEs $(\boldsymbol{B}, \boldsymbol{D}, \boldsymbol{F}, \boldsymbol{H})$. Thresholds were compared with 3-month-old WT and /s/1-TG mice, which had indistinguishable ABR and DPOAE at this age. Data are group means ( \pm SEM). Group sizes were as follows: 3 months: $n=4$ for control, $n=10$ for $/ s / 1-T G ; 6$ months: $n=4$ for control,$n=10$ for $/ s / 1-T G$; for 12 months: $n=4$ for control, $n=9$ for $/ s / 1-T G$; for 17 months: $n=4$ for control, $n=11$ for $/ s / 1$-TG. The up arrows indicate that at the highest SPLs tested some animals showed no response, which will cause an underestimation of threshold shift. For ANOVA analysis: 6 months: ABR: $F=11.31, * * p=0.0012 ; \mathrm{DPOAE}:$ $F=0.560 ; p=0.457 ; 12$ months: ABR: $F=7.636,{ }^{*} p=0.018 ;$ DPOAE: $F=1.773, p=0.210 ; 17$ months: ABR: $F=11.184 ;{ }^{* *} p=0.006 ;$ DPOAE: $F=11.554,{ }^{* *} p=0.005$.

connected components feature. For histology, $10 \mu \mathrm{m}$ paraffin sections of adult mouse cochleas were stained with hematoxylin/eosin following standard protocols. The number of nuclei of spiral ganglion neurons (SGNs) was counted for each half turn of the cochlear spiral on every fifth section of the series. The counts were expressed as the number of SGNs per $100 \mu \mathrm{m}^{2}$.

We used ImageJ on the images taken with the same setting of sectioned slides. This enabled us to determine the signal intensity of defined regions (e.g., nuclei of hair cells or supporting cells), to obtain average intensity of pixels per square micrometer, and thus to compare immunohistochemical signal intensity between Isl1-TG and control mice. A representative slide with three cross sections from each mouse cochlea was sampled, and three mice were used for each group. Student's $t$ test was performed for each labeling between Isl1-TG and WT control groups. The signal intensity was measured for proteins including ISL1, GFP, SOX2, p27, PTPRQ, and prestin.

\section{Results}

\section{The Isl1-TG mice}

To overexpress Isl 1 in hair cells, we created a transgenic line with Isl1 under control of the Pou 43 promoter, which has been shown to direct hair cell-specific expression (Sage et al., 2006). An EGFP reporter was inserted downstream of Isl1, separated by an IRES sequence (Fig. 1A). Three founder lines with different expression patterns of transgenes were obtained, and the line in which Isl1 was expressed in all auditory hair cells was chosen for subsequent study. The Isl1-TG mice are viable and fertile, with normal gross appearance and behavior, as well as normal life span. No tumors or other abnormalities were detected.

Isl1 is normally expressed in embryonic prosensory domain, then confined to early hair cells and supporting cells, while hair cell expression is normally absent by postnatal day (P) 0 (Huang et al., 2008). In the Isl1-TG mice, Isll immunolabeling was maintained postnatally in both cochlear hair cells and utricular hair cells. Isll staining in supporting cells and in the greater epithelial ridge was similar to controls, confirming that the transgene was not activated in nonhair cells (Fig. $1 D, E$ ). The EGFP reporter was detected in hair cells from Isl1-TG cochleas, including in the adult ear at 17 months (Fig. $1 B, C$ ).

While the anti-ISL1 antibody worked well in embryonic and neonatal cochlea sections, it failed to work in adult cochleas, likely due to the decalcification process involved. Instead we used anti-GFP, whose expression had been directly linked to Isl1 expression, both in young and adult hair cells (Fig. $1 B-E$ ). We further performed quantitative RT-PCR using 3-month-old utricles and cochleas and found significant upregulation of Isl1 transcript in the Isl1-TG compared with WT controls (Fig. 1F). In transfection performed in the HEK cells to evaluate production of Isl 1 transgene, Isl 1 was always localized in the same cells as GFP. We never detected GFP signal in postnatal WT cochlear hair cells or HEK cells transfected with control vector (data not shown).

Cochleas of Isl1-TG mice showed normal morphology and normal expression of markers for differentiating hair cells (PTPRQ, prestin, MYO7A; Fig. 2A-D,I,J), supporting cells (p27KIP1, PROX1, SOX2; Fig. 2C,D, G-J), and neurons (acetylated tubulin and neurofilament, Fig. $2 A, B, G, H)$. Hair bundles appeared normal and took up FM1-43 dye (Fig. $2 K, L$ ), indicating functional transduction channels. We further measured and compared signal intensities for hair cell and supporting cell labeling between Isl1-TG and control groups. The only significant difference was an increase in Isl1 and GFP signals in the Isl1-TG 
hair cells comparing to control groups (Isl1: 2.5 -fold increase, $p<0.05$; GFP: 1.5 fold increase, $p<0.01 ; n=3$ for each group), confirming the overexpression of Isll and GFP, but not other genes, in the transgenic hair cells (Fig. 2M). No significant difference was detected in supporting cell markers between Isl1-TG and WT (Fig. 2M). Using proliferating cell nuclear antigen (PCNA) as a proliferation marker, we saw no sign of cell division in the Isl1-TG cochlea (Fig. 2E,F), demonstrating Is1l overexpression does not result in renewed proliferation.

Islet 1 overexpression minimizes ARHL To test whether Isll overexpression affected ARHL, we measured ABRs at different ages. At 3 months, ABR thresholds in transgenics were virtually identical to WTs (Fig. $3 A, B$ ). At later ages, WTs showed the progressive high-frequency threshold shifts that characterize ARHL in the C57BL/6J strain (Erway et al., 1993; Hequembourg and Liberman, 2001; Fig. $3 C, E, G)$. By 17 months, thresholds had deteriorated by $>50 \mathrm{~dB}$, with respect to those seen at 3 months of age. In Isl1-TG mice, ABR threshold shifts were significantly smaller at all test frequencies (Fig. $3 C, E, G)$ : at 17 months, the age-related threshold elevation was 20-30 dB lower than in WTs at high frequencies.

While ABRs reflect the summed activity of the neural output of the cochlea, the DPOAEs are generated presynaptically, depending critically only on the normal function of the OHCs. At 3 months, similar DPOAEs were observed between Isl1-TG and WT mice, with an exception the control had a better DPOAE at 22.63 $\mathrm{kHz}$ (Fig. 3B). At later stages, the DPOAEs in the Isl1-TG were significantly lower than those of control inner ears (Fig. $3 D, F, H)$. The differences, however, were smaller than those seen in corresponding frequency regions via the ABR. This suggests that, in addition to possible differences originating in hair cells that would affect the DPOAE thresholds, there are also differences of neuronal origin that would produce additional effects on the $\mathrm{ABR}$ responses.

Histological analysis showed a corresponding difference in hair cell survival between the transgenics and their WT littermates. In the 17-19 month WT, there was significant hair cell loss in the basal half of the cochlea: all OHCs and more than half of the IHCs were absent (Fig. $4 A, C)$. In contrast, a majority of OHCs and most IHCs were preserved in the aged Isl1-TG cochleas (Fig. 4B,D). Quantifica-
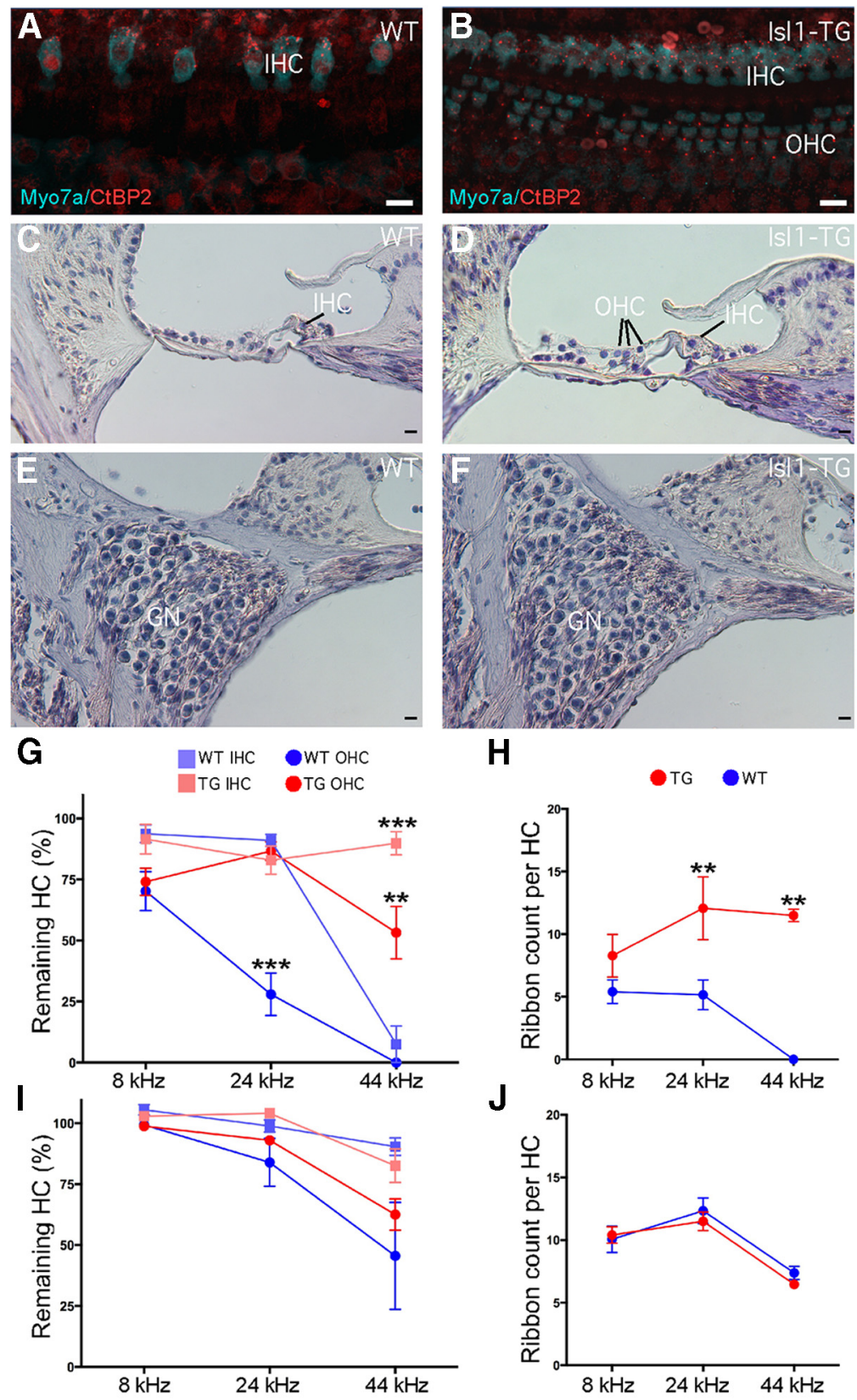

H

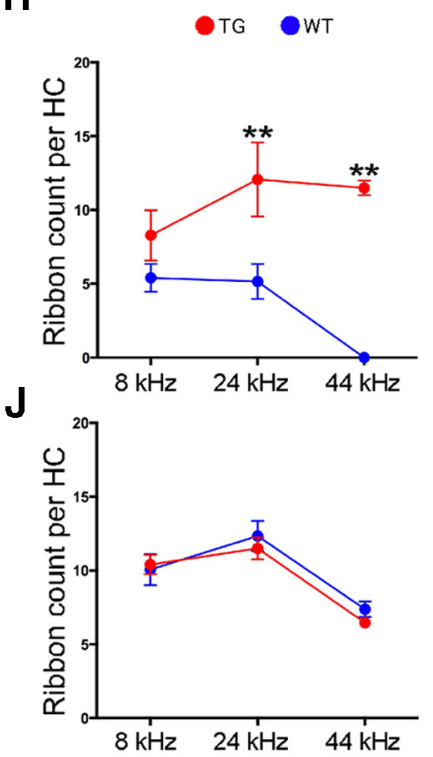

Figure 4. Survival of hair cells and preservation of presynaptic ribbons in aged $/ s / 1-T G$ cochleas. $A, B$, Confocal images from the $32 \mathrm{kHz}$ region in 19-month-old cochleas from an /s/1-TG and a WT. Hair cells are immunostained with antibodies to myosin VIIA (cyan); ribbons are stained with antibodies to CtBP2 (red). Scale bar, $10 \mu \mathrm{m}$. C, H\&E staining of a 17-month-old WT cochlea section to show OHC loss. D, H\&E staining of a 17-month-old $/ s / 1-T G$ cochlea section to show preservation of $0 \mathrm{HC}$ and the overall structure. $\boldsymbol{E}, \boldsymbol{F}, \mathrm{H} \&$ E staining of 15 -monthold WT and /s/1-TG mid-turn sections to show similar ganglion survival. G, Hair cell counts from 19-month-old animals of both genotypes show significant enhancement of survival in the basal half of the cochlea in the /s/1-TG. Data are group means ( \pm SEM). Group sizes were as follows: $n=8$ for TG; $n=7$ for WT. $\boldsymbol{H}$, At 19 months, the number of synaptic ribbons per hair cell was significantly reduced in the basal half of the cochlea in WT mice but preserved in the Is/1-TGs. I, J, At 3 months of age, the numbers of hair cells or ribbons were not significantly different in WT versus/s/1-TG mice. $\boldsymbol{K}$, By genomic PCR, a fragment of 194 bp for the Cdh23 ahl allele was amplified. Upon Pstl digestion, both Is/1-TG and WT showed a 170 bp fragment corresponding to the mutant $C d h 23$ ahl allele, whereas the 194 bp fragment remained in CBA/CaJ. $n=4$ in each comparison. ANOVA analysis: $\mathbf{G}, F=25.07,{ }^{* * *} p<0.001 ; \boldsymbol{H}, F=19.23,{ }^{* *} p<0.01$. 
A

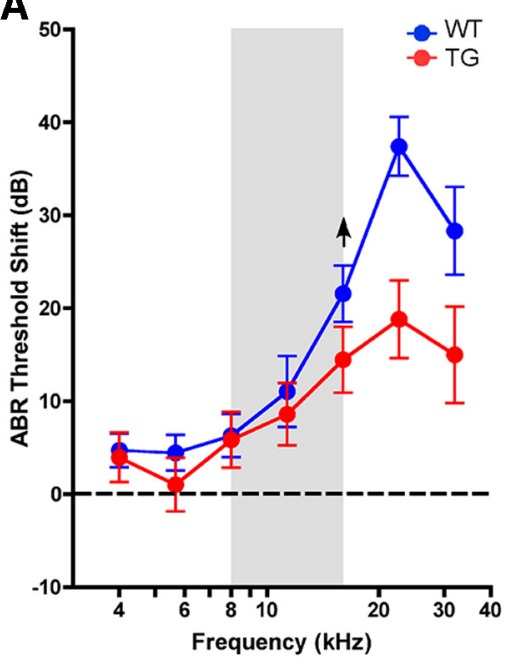

B

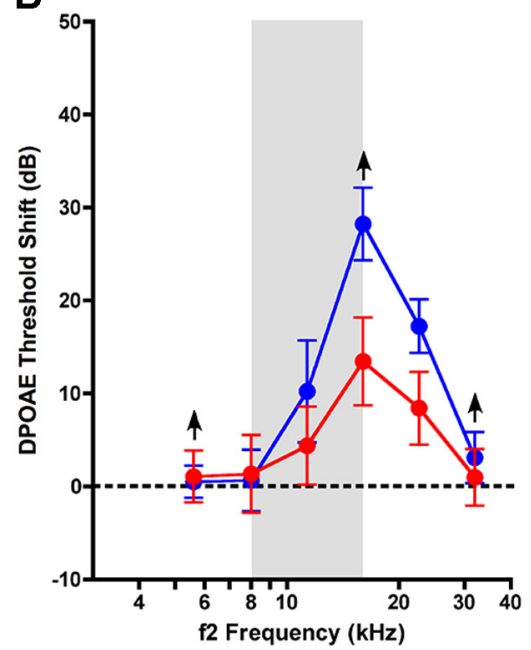

Figure 5. Noise-induced threshold shift is reduced in $/$ /17-TG mice compared with WT 2 weeks after noise exposure, as measured by either ABRs $(\boldsymbol{A})$ or DPOAEs $(\boldsymbol{B})$. Data are group means ( \pm SEM). Group sizes were as follows: $n=19$ for control, $n=30$ for Is/7-TG. The up arrow indicates a lack of response in some animals at the highest SPLs tested, which could lead to an underestimated threshold shift. ANOVA analysis: ABR: $F=4.718,{ }^{*} p=0.035$; DPOAE: $F=1.205, p=0.278$.
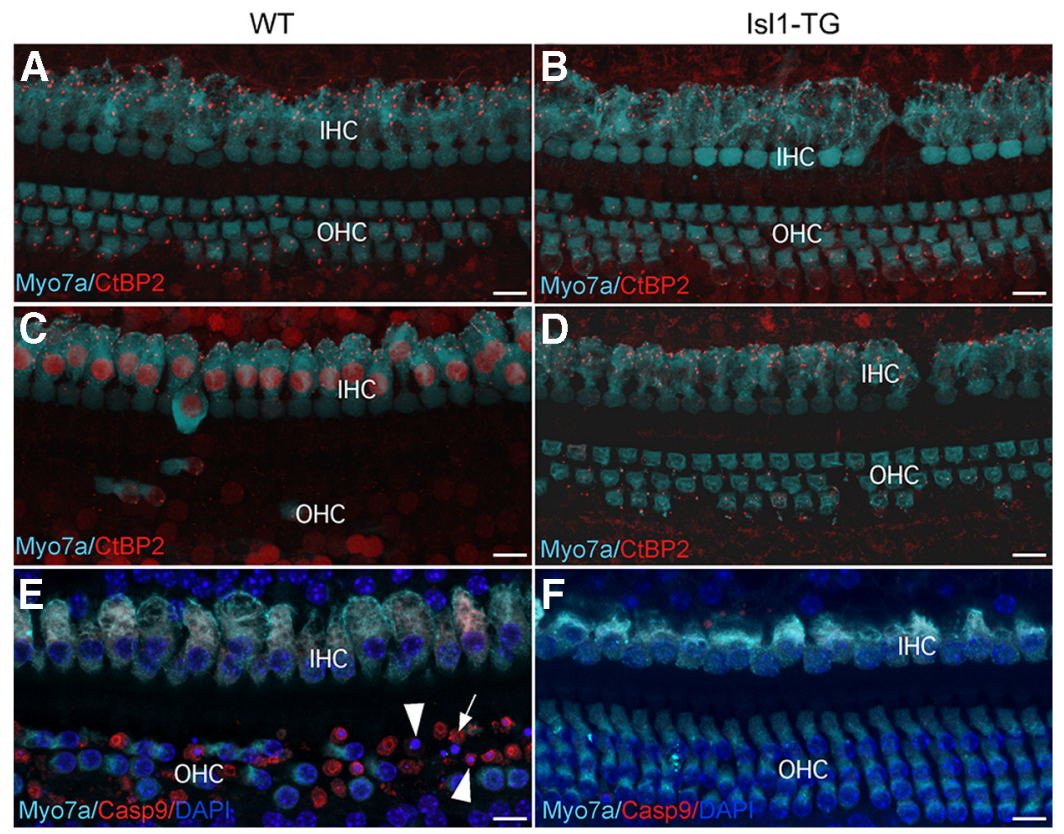

Figure 6. Hair cell survival in $/ s / 1-T G$ after intense noise exposure. $A, B, 0$ ne month after $100 \mathrm{~d} B$ exposure, in both $W T$ and $/ s / 1-T G$ mice, most $\mathrm{OHCs}$ survived with a few missing $\mathrm{OHCs}$. The number of ribbon counts was also similar (CtBP2 labeling). C, D, 2 months after $116 \mathrm{~dB}$ exposure, WT mice exhibited major $\mathrm{OHC}$ loss, whereas in /S/1-TG mice most OHCs survived. $\boldsymbol{E}$, Twenty-one hours after $116 \mathrm{~dB}$ exposure, many WT OHCs were labeled with cleaved Casp9 (arrow), and many condensed nuclei (arrowheads) were seen in the basal half of the cochlea. $F$, In /s/1-TG cochlea from the similar region, no Casp9-positive hair cells were detected. Scale bar, 10 $\mu \mathrm{m}$.

tion confirmed a highly significant reduction in hair cell number in the Isl1-TG mice (Fig. 4G), whereas at 3 months, the Isl1-TG and control cochleas had similar number of hair cells (Fig. 4I). The significant basal-turn hair cell loss in the transgenic ears mirrors the minimization of high-frequency threshold shifts in the ABRs. Isll thus promotes hair cell survival in aging inner ear.

The synapses between IHCs and the cochlear nerve terminals are marked by a prominent presynaptic ribbon, which can be immunostained with antibodies to CtBP2. In the aged WT cochlea, there was a striking reduction in the numbers of synaptic ribbons on the remaining IHCs. Many more synaptic ribbons remained in all regions of the Isl1-TG cochlea. Quantification showed that the differences were statistically significant throughout the basal half of the cochlea (Fig. $4 H$ ), but no difference was found in the number of CtBP2 counts in 3-month-old Isl1-TG and control mice (Fig. 4J). We also counted ganglion neurons in the middle region of both Isl1-TG and control mice (Fig. $4 E, F$ ), and did not detect significant difference in their numbers between the two groups (data not shown).

We performed genotyping of $C d h 23^{\text {ahl }}$ mutation in the mice used in our study. All mice were homozygous for $C d h 23^{\text {ahl }}$ mutant allele (Fig. $4 K$ ), an indication that they are C57BL/6J background, correlating with ARHL known to be associated with the strain.

\section{Islet 1 overexpression minimizes NIHL}

To study whether Isll expression in hair cells also offers protection from NIHL, we first studied a noise exposure designed to produce a moderate degree of permanent threshold shift. Such exposures produce minimal hair cell loss except at the extreme base of the cochlea (Wang et al., 2002). The threshold elevation may be caused by damage to the stereocilia bundles required for mechanoelectric transduction (Liberman and Dodds, 1984). Young mice (6-7 weeks) of both genotypes were exposed to octave-band noise at $8-16 \mathrm{kHz}$ for $2 \mathrm{~h}$ at $100 \mathrm{~dB}$ SPL. Two weeks later, after temporary components of the damage recovered, threshold, as seen by either ABRs or DPOAEs, was elevated by up to $40 \mathrm{~dB}$ in the WT ears (Fig. $5 A, B)$. The maximum damage is shifted to frequencies slightly above the exposure band (Fig. $5 A$ ), as expected given the classic half-octave shift in NIHL (Cody and Johnstone, 1981). For the Isl1-TG littermates, mean threshold shifts were lower, and the differences were statistically significant ( $p<0.001$ at $22.63 \mathrm{kHz}, t$ test).

Histological analysis showed hair cell loss only at the extreme base, at frequency regions $>45 \mathrm{kHz}$ (see Fig. 7A). Although the mean loss was smaller in the TG than in the WT ears, the differences were not statistically significant. Counts of synaptic ribbons failed to reveal any difference in the degree of neuropathy between WT and TG ears (Figs. 6A, $B, 7 B$ ).

To better assess whether Isll overexpression is involved in minimizing noise-induced hair cell death, we exposed new groups of animals at a higher intensity (116 dB SPL). After exposure, both Isl1-TG and WT mice showed no ABR or DPOAE responses at any frequencies, which is consistent with a previous study (Wang et al., 2002). Three weeks after exposure, in WT mice, virtually all OHCs from basal and middle regions were 
missing, whereas most OHCs in the Isl1-TG cochlea were preserved (Figs. $6 C, D, 7 C)$. There was no significant difference in the ribbon counts (Fig. 7D). To demonstrate that hair cell loss is a direct result of apoptosis, we performed immunostaining for an apoptotic marker cleaved caspase-9 (Casp9) $24 \mathrm{~h}$ after exposure. A large number of Casp9-labeled $\mathrm{OHCs}$ with condensed nuclei were seen in WT ears in the basal and middle turns (Fig. 6E). In contrast, in the Isl1-TG cochlea, fewer caspase-positive OHCs were detected in the same region (Fig. $6 F$ ). Thus rapid apoptosis after $116 \mathrm{~dB}$ exposure led to the absence of OHCs in WT mice, whereas OHCs survived in the Isl1-TG mice.

\section{Discussion}

This study provides evidence that hair cell overexpression of Isl1, an inner ear progenitor gene, provides significant protection from both ARHL and NIHL in mice.

Isl1 is one of the most conserved mammalian genes critical in development in multiple systems. A crucial early role of Isl1 was demonstrated by heart development arrest and lethality in the Isll germline knock-out (Ahlgren et al., 1997), with disrupted pancreas and motor neuron development (Pfaff et al., 1996). Isl1 plays important roles in differentiated cells. Inducible Isll deletion in the pancreas at embryonic day (E) 13.5 severely disrupted proliferation and survival of the later insulin-producing islet cells (Du et al., 2009). Further, Isl1 overexpression suppressed endogenous Lhxl expression and increased type II horizontal cells in chick retina (Suga et al., 2009), whereas Isll overexpression led to severe growth deficiencies in mesodermal tissues by inhibiting cell division (Muller et al., 2003; Kappen et al., 2013).

In chicken, $I s l 1$ is prominently expressed in adult supporting cells and hair cells (Li et al., 2004), in contrast to its expression in embryonic hair cells and early supporting cells in mouse (Huang et al., 2008). Sustained Isll expression in adult chicken inner ear may contribute to hair cell regeneration potential. Also, Isl1 marks stem cells in postmitotic tissues, including heart (Laugwitz et al., 2005). We hypothesized that the lack of Isll expression in the adult mouse inner ear might play a role in maintaining the highly differentiated state that contributes to its lack of regenerative capacity. We thus forced Isll expression in mature hair cells with a goal of reactivating progenitor genes to achieve renewed proliferation and hair cell regeneration. We did not observe an effect on proliferation or hair cell regeneration. As continuous expression of progenitor genes could affect hair cell differentiation and hearing, we evaluated cochlear function in aging and noise-exposed Isl1-TG mice. To our surprise, we observed normal hair cell development and hearing protection during aging and after noise exposure, as the result of hair cell survival and synapse preservation.

The minimization of both ARHL and NIHL by Is $1 l$ overexpression suggests a common mechanism underlying the two types of hearing loss in our models. The type of ARHL in our
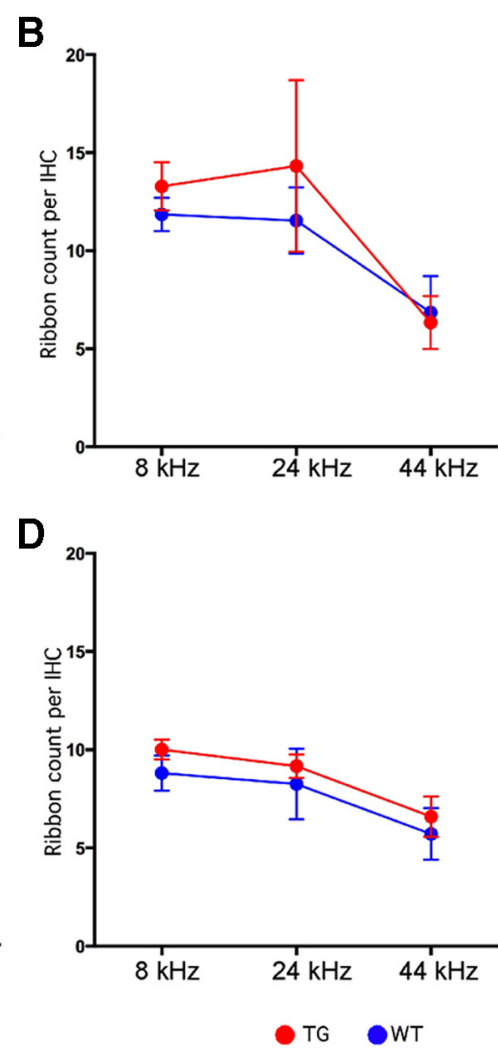

Figure 7. Hair cell survival is enhanced after $116 \mathrm{~dB}$ noise in $/ s / 1-T G$ mice. $A, B$, No significant difference in hair cell survival or ribbon counts was seen between /s/1-TG and WT mice 1 month after $100 \mathrm{~dB}$ exposure. $C$, After the $116 \mathrm{~dB}$ exposure, the $0 \mathrm{HC}$ loss was significantly larger in some regions in WTs than in $/$ s/1-TGs. ANOVA, $F=55.20,{ }^{* * *} p<0.001 ; n=5$ for TG; $n=6$ for WT. $D$ There were no differences in the synaptic ribbon counts between $/ s / 1-T G$ and WT.

transgenic line is presumably the same as that seen in C57BL/6J, which was one of the parent strains used for backcrossing. All Isl1-TG mice and their control littermates were homozygous for the Cdh23 mutant allele (Fig. $4 K$ ). The basis for premature hearing loss in C57BL/6J is an allelic variation ( $a h l)$ in cadherin 23 (Cdh23; Noben-Trauth et al., 2003), an essential component of the tip links that couple motion of the hair cell stereocilia to the transduction channels (Siemens et al., 2004). The age-related,

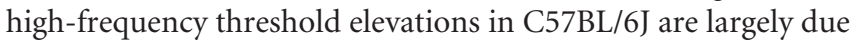
to hair cell loss throughout the cochlea, as was observed in the WT mice in the study. Apoptosis has also been associated with ARHL in the inbred strain CBA (Tadros et al., 2008), suggesting a general role of apoptosis underlying ARHL. Attenuation of apoptosis may offer a common mechanism for the protection against AHRL.

Hair cell overexpression of Isl1 compensated the defect induced by ahl mutation, resulting in enhanced hair cell survival in the basal half of the cochlea in the older animals (Fig. $4 B, D$ ), with a corresponding minimization of the associated cochlear threshold elevation (Fig. 3). Further preservation of CtBP2 was seen in older Isl1-TG (Fig. 4A, B,H). In old WT control, the threshold shifts in $\mathrm{ABR}$ were greater than shifts in DPOAE, indicating deficits of neuronal origin (e.g., reduction in synaptic ribbons), in addition to hair cell loss, were likely contributing to hearing loss. The combination of hair cell survival and preservation of synapses thus contributed to overall hearing preservation in the old Isl1-TG mice. The number of ganglion cells was not significantly different between Isl1-TG and WT, supporting the involvement of synapses rather than cell bodies in the deterioration of hearing in old WT mice. 
After high-level noise exposure (116 dB), permanent threshold elevations are also due, at least in part, to hair cell death (Fig. 7C). Apoptosis is involved in NIHL and apoptosis inhibition reduces NIHL (Someya and Prolla, 2010; Op de Beeck et al., 2011). The prominent Casp9 labeling in the WT but not in the Isl1-TG hair cells (Fig. 6E,F) supports a better suppression of noiseinduced apoptosis and ultimate hair cell survival in the transgenics exposed to the high-level $116 \mathrm{~dB}$ noise. Previous studies have shown that intense noise induces significant $\mathrm{OHC}$ loss, damage to the stereocilia on surviving hair cells, and defects in other regions, including fibrocytes and stria vascularis (Wang et al., 2002). Despite hair cell survival in the Isll-TG mice exposed to $116 \mathrm{~dB}$ noise, ABR responses were still greatly attenuated, indicating other factors are likely responsible for hearing loss in the Isll-TG under the intense noise condition. The Isl1-TG model is therefore useful in dissecting out other contributors to hearing loss after intense noise exposure.

After noise exposure at $100 \mathrm{~dB}$, WT mice showed significant threshold elevation (Fig. 5), whereas Isll overexpression reduced this functional loss, despite hair cell survival in both genotypes (Fig. 7). Although we did not study stereocilia condition, prior reports have shown that this type of moderate $(40 \mathrm{~dB})$ permanent NIHL is well explained by the disarray, fusion, and loss of stereocilia on both IHCs and OHCs (Liberman and Dodds, 1984; Wang et al., 2002). The effects of Isl1 overexpression at these more moderate sound pressures reveal that the protective effects are not restricted to antiapoptosis activity. Moderate level exposures can cause degeneration of cochlear neurons, despite survival of the hair cells, due to glutamate excitotoxicity (Kujawa and Liberman, 2006). This primary neural degeneration is first seen as a loss of synaptic ribbons in the IHCs. Our analysis of the transgenics (Fig. $7 B, D$ ) suggests that the Isll overexpression may minimize this type of primary neural degeneration.

What is the mechanism underlying Isll-mediated hair cell survival and hearing preservation? Isl1 may activate progenitor genes in aged and noise-damaged hair cells, and confer the capacity to repair and survive. For instance, it is known that newborn mammalian hair cells can repair tip links and restore mechanotransduction after tip-link damage (Jia et al., 2009). Isl1 is known to regulate different target genes and pathways: it interacts with Lhx3 in the nervous system (Thaler et al., 2002; Song et al., 2009; Lee et al., 2012), it interacts with Wnt and Bmp in heart (Yang et al., 2006; Cohen et al., 2007), it coregulates retinal ganglion development with Pou4f2 (Mu et al., 2008; Pan et al., 2008), and it downregulates Mafa to promote islet cell development in pancreas (Du et al., 2009). We have studied some known Isl1 targets in Isll-TG mice by semiquantitative RT-PCR and did not detect expression level change compared to control, an indication of targets with hair cell specificity. We are also performing nextgeneration sequencing to profile purified Isll and control hair cells. Preliminary data suggest suppression of Tnf- $\alpha$ pathway by Isl1 overexpression (sequencing data were deposited in https://shield.hms.harvard.edu/). Tnf- $\alpha$ is upregulated after noise exposure and is shown to recruit inflammatory cells to the cochlea that cause hair cell death (Fujioka et al., 2006; Keithley et al., 2008). Further inhibition of Tnf- $\alpha$ offers protection against NIHL (Arpornchayanon et al., 2013). Thus, Isll-mediated protection against NIHL may involve suppression of inflammatory pathways after noise damage. To confirm the Tnf- $\alpha$ pathway involvement and to identify additional genes and pathways, we are studying expression profiles of $I s l 1$ and control hair cells after noise damage and in aged mice.

To our knowledge, our model is the first in which expression of a single gene in postnatal hair cells results in hair cell survival and hearing preservation in mice that otherwise suffer from ARHL and NIHL. Prior studies of cochlear protection have involved a number of pathways, including antioxidant pathways, antiapoptotic pathways, stress-related pathways, and the cholinergic pathways controlling feedback suppression of the cochlear amplifier (Henderson et al., 2006; Bielefeld et al., 2010; Wei et al., 2010; Op de Beeck et al., 2011; Kidd Iii and Bao, 2012). In our model, hair cell-specific Isll expression is driven, from E14 onwards, by the Pou $4 \mathrm{f3}$ promoter. Throughout embryonic development, endogenous Isll is expressed in hair cells and supporting cells. Thus, additional Isl1 expression in hair cells is unlikely to affect their development. The hearing preservation and enhanced hair cell survival are likely the result of Isll function in postnatal hair cells. For future work, it is important to determine whether acute Isll activation in adult hair cells enhances their survival after noise exposure and during aging. Study of the Isl 1 transgene in other inbred strains with ARHL and NIHL will address whether hearing protection is general or strain specific. Strategy to use the information for hearing protection could explore the screening of small molecules that activate Isll or its downstream effectors in the inner ear or use gene delivery to overexpress Isll in adult hair cells. Finally it will be interesting to investigate whether overexpression of other inner ear progenitor genes in mature hair cells could lead to similar hearing protection.

\section{References}

Ahlgren U, Pfaff SL, Jessell TM, Edlund T, Edlund H (1997) Independent requirement for ISL1 in formation of pancreatic mesenchyme and islet cells. Nature 385:257-260. CrossRef Medline

Arpornchayanon W, Canis M, Ihler F, Settevendemie C, Strieth S (2013) TNF-alpha inhibition using etanercept prevents noise-induced hearing loss by improvement of cochlear blood flow in vivo. Int J Audiol 52:545552. CrossRef Medline

Bielefeld EC, Tanaka C, Chen GD, Henderson D (2010) Age-related hearing loss: is it a preventable condition? Hear Res 264:98-107. CrossRef Medline

Cai CL, Liang X, Shi Y, Chu PH, Pfaff SL, Chen J, Evans S (2003) Isl1 identifies a cardiac progenitor population that proliferates prior to differentiation and contributes a majority of cells to the heart. Dev Cell 5:877-889. CrossRef Medline

Cody AR, Johnstone BM (1981) Acoustic trauma: single neuron basis for the "half-octave shift". J Acoust Soc Am 70:707-711. Medline

Cohen ED, Wang Z, Lepore JJ, Lu MM, Taketo MM, Epstein DJ, Morrisey EE (2007) Wnt/beta-catenin signaling promotes expansion of Isl-1-positive cardiac progenitor cells through regulation of FGF signaling. J Clin Invest 117:1794-1804. CrossRef Medline

Du A, Hunter CS, Murray J, Noble D, Cai CL, Evans SM, Stein R, May CL (2009) Islet-1 is required for the maturation, proliferation, and survival of the endocrine pancreas. Diabetes 58:2059-2069. CrossRef Medline

Elshatory Y, Gan L (2008) The LIM-homeobox gene Islet-1 is required for the development of restricted forebrain cholinergic neurons. J Neurosci 28:3291-3297. CrossRef Medline

Erway LC, Willott JF, Archer JR, Harrison DE (1993) Genetics of age-related hearing loss in mice: I. Inbred and F1 hybrid strains. Hear Res 65:125-132. CrossRef Medline

Erway LC, Shiau YW, Davis RR, Krieg EF (1996) Genetics of age-related hearing loss in mice. III. Susceptibility of inbred and F1 hybrid strains to noise-induced hearing loss. Hear Res 93:181-187. CrossRef Medline

Fujioka M, Kanzaki S, Okano HJ, Masuda M, Ogawa K, Okano H (2006) Proinflammatory cytokines expression in noise-induced damaged cochlea. J Neurosci Res 83:575-583. CrossRef Medline

Henderson D, Bielefeld EC, Harris KC, Hu BH (2006) The role of oxidative stress in noise-induced hearing loss. Ear Hear 27:1-19. CrossRef Medline

Henry KR, Chole RA (1980) Genotypic differences in behavioral, physiological and anatomical expressions of age-related hearing loss in the laboratory mouse. Audiology 19:369-383. CrossRef Medline

Hequembourg S, Liberman MC (2001) Spiral ligament pathology: a major 
aspect of age-related cochlear degeneration in C57BL/6 mice. J Assoc Res Otolaryngol 2:118-129. Medline

Hobert O, Westphal H (2000) Functions of LIM-homeobox genes. Trends Genet 16:75-83. CrossRef Medline

Huang M, Sage C, Li H, Xiang M, Heller S, Chen ZY (2008) Diverse expression patterns of LIM-homeodomain transcription factors (LIM-HDs) in mammalian inner ear development. Dev Dyn 237:3305-3312. CrossRef Medline

Jia S, Yang S, Guo W, He DZ (2009) Fate of mammalian cochlear hair cells and stereocilia after loss of the stereocilia. J Neurosci 29:15277-15285. CrossRef Medline

Kappen C, Yaworsky PJ, Muller YL, Salbaum JM (2013) Transgenic studies on homeobox genes in nervous system development: spina bifida in Isl1 transgenic mice. Transgenic Res 22:343-358. CrossRef Medline

Karlsson O, Thor S, Norberg T, Ohlsson H, Edlund T (1990) Insulin gene enhancer binding protein Isl-1 is a member of a novel class of proteins containing both a homeo- and a Cys-His domain. Nature 344:879-882. CrossRef Medline

Keithley EM, Wang X, Barkdull GC (2008) Tumor necrosis factor alpha can induce recruitment of inflammatory cells to the cochlea. Otol Neurotol 29:854-859. CrossRef Medline

Kidd Iii AR, Bao J (2012) Recent advances in the study of age-related hearing loss: a mini-review. Gerontology 58:490-496. CrossRef Medline

Kujawa SG, Liberman MC (2006) Acceleration of age-related hearing loss by early noise exposure: evidence of a misspent youth. J Neurosci 26: 2115-2123. CrossRef Medline

Kujawa SG, Liberman MC (2009) Adding insult to injury: cochlear nerve degeneration after "temporary" noise-induced hearing loss. J Neurosci 29:14077-14085. CrossRef Medline

Laugwitz KL, Moretti A, Lam J, Gruber P, Chen Y, Woodard S, Lin LZ, Cai CL, Lu MM, Reth M, Platoshyn O, Yuan JX, Evans S, Chien KR (2005) Postnatal isl $1+$ cardioblasts enter fully differentiated cardiomyocyte lineages. Nature 433:647-653. CrossRef Medline

Lee S, Cuvillier JM, Lee B, Shen R, Lee JW, Lee SK (2012) Fusion protein Isl1-Lhx3 specifies motor neuron fate by inducing motor neuron genes and concomitantly suppressing the interneuron programs. Proc Natl Acad Sci 109:3383-3388. CrossRef Medline

Li H, Liu H, Sage C, Huang M, Chen ZY, Heller S (2004) Islet-1 expression in the developing chicken inner ear. J Comp Neurol 477:1-10. CrossRef Medline

Liberman MC, Dodds LW (1984) Single-neuron labeling and chronic cochlear pathology. III. Stereocilia damage and alterations of threshold tuning curves. Hearing Res 16:55-74. CrossRef Medline

Liberman MC, Gao J, He DZ, Wu X, Jia S, Zuo J (2002) Prestin is required for electromotility of the outer hair cell and for the cochlear amplifier. Nature 419:300-304. CrossRef Medline

Lin L, Bu L, Cai CL, Zhang X, Evans S (2006) Isl1 is upstream of sonic hedgehog in a pathway required for cardiac morphogenesis. Dev Biol 295:756-763. CrossRef Medline

Mashimo T, Erven AE, Spiden SL, Guénet JL, Steel KP (2006) Two quantitative trait loci affecting progressive hearing loss in 101/H mice. Mamm Genome 17:841-850. CrossRef Medline

Mu X, Fu X, Beremand PD, Thomas TL, Klein WH (2008) Gene regulation logic in retinal ganglion cell development: Isl1 defines a critical branch distinct from but overlapping with Pou4f2. Proc Natl Acad Sci 105:69426947. CrossRef Medline

Muller YL, Yueh YG, Yaworsky PJ, Salbaum JM, Kappen C (2003) Caudal dysgenesis in Islet-1 transgenic mice. FASEB J 17:1349-1351. Medline

National Institute for Occupational Safety and Health (2001) Fact sheet: work related hearing loss. DHHS (NIOSH) publication number 2001103. Atlanta: Centers for Disease Control and Prevention.

Noben-Trauth K, Zheng QY, Johnson KR (2003) Association of cadherin 23 with polygenic inheritance and genetic modification of sensorineural hearing loss. Nat Genet 35:21-23. CrossRef Medline

Op de Beeck K, Schacht J, Van Camp G (2011) Apoptosis in acquired and genetic hearing impairment: the programmed death of the hair cell. Hear Res 281:18-27. CrossRef Medline

Pan L, Deng M, Xie X, Gan L (2008) ISL1 and BRN3B co-regulate the differentiation of murine retinal ganglion cells. Development 135:19811990. CrossRef Medline

Pfaff SL, Mendelsohn M, Stewart CL, Edlund T, Jessell TM (1996) Requirement for LIM homeobox gene Isl1 in motor neuron generation reveals a motor neuron-dependent step in interneuron differentiation. Cell 84: 309-320. CrossRef Medline

Sage C, Huang M, Vollrath MA, Brown MC, Hinds PW, Corey DP, Vetter DE, Chen ZY (2006) Essential role of retinoblastoma protein in mammalian hair cell development and hearing. Proc Natl Acad Sci U S A 103:73457350. CrossRef Medline

Schoenborn CA, Heyman KM (2009) Health characteristics of adults aged 55 years and over: United States, 2004-2007. In: National health statistics report. Hyattsville, MD: National Center for Health Statistics.

Siemens J, Lillo C, Dumont RA, Reynolds A, Williams DS, Gillespie PG, Muller U (2004) Cadherin 23 is a component of the tip link in hair-cell stereocilia. Nature 428:950-955. CrossRef Medline

Someya S, Prolla TA (2010) Mitochondrial oxidative damage and apoptosis in age-related hearing loss. Mech Ageing Dev 131:480-486. CrossRef Medline

Song MR, Sun Y, Bryson A, Gill GN, Evans SM, Pfaff SL (2009) Islet-toLMO stoichiometries control the function of transcription complexes that specify motor neuron and V2a interneuron identity. Development 136:2923-2932. CrossRef Medline

Spongr VP, Flood DG, Frisina RD, Salvi RJ (1997) Quantitative measures of hair cell loss in CBA and C57BL/6 mice throughout their life spans. J Acoust Soc Am 101:3546-3553. CrossRef Medline

Suga A, Taira M, Nakagawa S (2009) LIM family transcription factors regulate the subtype-specific morphogenesis of retinal horizontal cells at post-migratory stages. Dev Biol 330:318-328. CrossRef Medline

Sun Y, Dykes IM, Liang X, Eng SR, Evans SM, Turner EE (2008) A central role for Islet1 in sensory neuron development linking sensory and spinal gene regulatory programs. Nat Neurosci 11:1283-1293. CrossRef Medline

Tadros SF, D'Souza M, Zhu X, Frisina RD (2008) Apoptosis-related genes change their expression with age and hearing loss in the mouse cochlea. Apoptosis 13:1303-1321. CrossRef Medline

Thaler JP, Lee SK, Jurata LW, Gill GN, Pfaff SL (2002) LIM factor Lhx3 contributes to the specification of motor neuron and interneuron identity through cell-type-specific protein-protein interactions. Cell 110:237-249. CrossRef Medline

Trune DR, Kempton JB, Mitchell C (1996) Auditory function in the C3H/ $\mathrm{HeJ}$ and $\mathrm{C} 3 \mathrm{H} / \mathrm{HeSnJ}$ mouse strains. Hear Res 96:41-45. CrossRef Medline

Wang Y, Hirose K, Liberman MC (2002) Dynamics of noise-induced cellular injury and repair in the mouse cochlea. J Assoc Res Otolaryngol 3:248 268. CrossRef Medline

Wei L, Ding D, Salvi R (2010) Salicylate-induced degeneration of cochlea spiral ganglion neurons-apoptosis signaling. Neuroscience 168:288-299. CrossRef Medline

White JA, Burgess BJ, Hall RD, Nadol JB (2000) Pattern of degeneration of the spiral ganglion cell and its processes in the C57BL/6J mouse. Hear Res 141:12-18. CrossRef Medline

Yang L, Cai CL, Lin L, Qyang Y, Chung C, Monteiro RM, Mummery CL, Fishman GI, Cogen A, Evans S (2006) IsllCre reveals a common Bmp pathway in heart and limb development. Development 133:1575-1585. CrossRef Medline 